\title{
Does propagation method affect the field performance of peach trees?
}

\section{O método de propagação influencia o desempenho de pessegueiro?}

\author{
André Luiz Kulkamp de Souza ${ }^{1 *}$; Márcia Wulff Schuch²; Samila Silva Camargo ${ }^{3}$; \\ Robson Rodrigues Pereira ${ }^{4}$; Edson Luiz de Souza ${ }^{5}$; Mateus da Silveira Pasa ${ }^{1}$
}

\begin{abstract}
Worldwide, peach propagation has been performed mainly by grafting scions of desirable cultivars on rootstocks obtained from seeds. There are, however, other potential propagation methods not widely adopted due to the limited reports on the field performance of the resultant trees. This study addressed this knowledge gap and investigated the field performance of peach trees of the cultivar Maciel that were established in an orchard $(5.0 \mathrm{~m} \times 1.4 \mathrm{~m}$ spacing $)$ in 2011. The trees were trained in a "Y" system, with seedlings from three propagation techniques: 1) Conventional System (CS) - vegetative bud grafting of the scion on the rootstock of the Okinawa cultivar obtained from seed;2) Rootstock by Minicutting (RM) - vegetative bud grafting of the scion on the rootstock of the Okinawa cultivar obtained by minicutting in a semi-hydroponic system; 3) Self-Rooting (SR) - self-rooting of the scion in a semihydroponic system. The vegetative, productive, and fruit quality parameters were assessed during 2012 and 2013. The Maciel peach trees that were propagated by the SR technique were found to have similar or even superior field performance to those propagated by the CS. The RM propagation method was also found to be an important potential alternative to peach propagation, since this it combines two techniques (cutting and grafting) to reduce tree vigor, especially if the goal is high-density planting. Key words: Prunus persica. Cloning. Self-rooting. Minicutting.
\end{abstract}

\section{Resumo}

Em todo o mundo, a propagação de pessegueiro tem sido realizada principalmente por enxertia de cultivares copa em porta-enxertos obtidos a partir de sementes. No entanto, existem outros métodos de propagação potenciais que não são amplamente adotados devido à pouca informação em relação ao desempenho a campo das plantas. A fim de responder a esta pergunta, em 2011, pessegueiros da cultivar Maciel foram plantados (5,0m $\times 1,4 \mathrm{~m}$ de espaçamento) em um sistema de condução em "Y", com mudas oriundas de três diferentes técnicas de propagação. 1) Sistema Convencional (CS) - enxertia da copa sobre o porta-enxerto 'Okinawa' obtido por semente; 2) Porta-enxerto clonado (RM) - enxertia da copa sobre o porta-enxerto 'Okinawa' obtido por miniestaquia em sistema semi-hidropônico; 3) Autoenraizamento (SR) - autoenraizamento da copa em sistema semi-hidropônico. No período de três

1 Pesquisadores, Empresa de Pesquisa Agropecuária de Santa Catarina, Epagri, Videira, SC, Brasil. E-mail: andreluizks@yahoo. com.br; mateus.pasa@gmail.com

2 Profs., Faculdade de Agronomia Eliseu Maciel, Universidade Federal de Pelotas, UFPel, Capão do Leão, RS, Brasil. E-mail: mwschuch@ufpel.edu.br

3 Discente de Doutorado, Centro Agroveterinário, Universidade do Estado de Santa Catarina, UDESC, Lages, SC, Brasil. E-mail: samilasc@yahoo.com.br

4 Discente de Gradução, Faculdade de Agronomia Eliseu Maciel, Universidade Federal de Pelotas, UFPel, Capão do Leão, RS, Brasil. E-mail: robsonpereira_rp@hotmail.com

5 Prof., Universidade do Oeste de Santa Catarina, Videira, UNOESC, SC, Brasil. E-mail: edsonluizdesouza@gmail.com

* Author for correspondence

Received: June 29, 2016 Approved: Jan. 16, 2017 
anos, foram avaliadas variáveis vegetativas, produtivas e de qualidade dos frutos. Concluiu-se que o sistema de produção da muda por semi-hidroponia proporcionou plantas de qualidade igual ou superior ao método tradicional, tornando-se uma alternativa de propagação de pessegueiro. Além disso, o método de propagação RM parece ser uma alternativa importante para a propagação de pessegueiro quando o objetivo for o plantio de alta densidade, uma vez que este combina duas técnicas para reduzir o vigor da planta.

Palavras-chave: Prunus persica. Clonagem. Autoenraizamento. Miniestaca.

The production of peach seedlings, Prunus persica, in Brazil is mainly achieved by vegetative bud grafting, where the rootstocks are obtained from seeds (TOFANELLI et al., 2005). This rootstock propagation method, however, may result in the loss of desirable genetic traits, resulting in trees distinct from the mother tree. The search for new and more desirable techniques for peach propagation is, therefore, necessary.

Cutting propagation is an alternate technique that is used to substitute sexual propagation because it: 1) facilitates the production process; 2) reduces the time necessary for seedling production; 3) avoids genetic variability; and 4) could be used for both rootstock and scion propagation (OLIVEIRA et al., 2003; CARDOSO et al., 2011). The main drawback of cutting propagation, however, is the slow seedling growth after rooting of the cuttings. In addition, peach cultivars have been found to have difficulty in forming adventitious roots when using conventional cutting propagation methods (TSIPOURIDIS et al., 2006; TWORKOSKI; TAKEDA, 2007).

Soilless cultivation is another option for certificated peach seedling production. The scion cultivar is grafted on rootstocks cloned by minicuttings or cloning of the scion cultivar by self-rooting (SCHUCH; PEIL, 2012). Hydroponic or semi-hydroponic systems could be used by nurseries to improve these methods. In such soilless techniques, seedlings are grown in nutritive solutions, which enables out-of-season seedling production, induces precocity, lowers disease and pest occurrence, optimizes physical space, and reduces the risks associated with climatic adversities, thereby resulting in the production of healthier seedlings.

An investigation by Tomaz (2014), which involved semi-hardwood cutting propagation in a semi-hydroponic system using sand as the substrate, demonstrated the favorability of a soilless technique. The resultant plants in this study were found to have average lengths that were three times longer than those from an independent study that was conducted during the same time frame, which involved a conventional system (CS), (PICOLOTTO et al., 2007). In addition, the semihydroponic system resulted in a faster attainment of suitable trunk diameter for grafting than the CS technique. Despite these promising rooting and development results, most of the productive sector (i.e. growers and nurseries) have not adopted this propagation method mainly because of the lack of supporting information about the field performance of trees propagated by cuttings.

Field performance studies involving trees originating from different propagation methods have been conducted for fruit trees such as olive (BATI et al., 2006) and blueberry (SOUZA et al., 2012), amongst others. The field performance of peach trees has been found to be distinct among cultivars and sites (MARÍN et al., 2003; HAMMERSCHLANG; SCORZA, 1991); however, little is known about the specific influence of propagation methods. The aim of this study was to address this gap in understanding and investigate the influence of propagation method on the field performance of Maciel cultivar peach trees.

Peach seedlings used in this study were produced in Capão do Leão-RS/Brazil (31 $41^{\prime} 12.48^{\prime \prime}$ S, $\left.52^{\circ} 30^{\prime} 34.08^{\prime \prime} \mathrm{W}\right)$ via three propagation methods. 
The procedures and treatments involved in these propagation techniques are detailed as follows:

\section{Conventional System (CS)}

In spring 2010, rootstocks were obtained from seeds of Okinawa that had been treated with cold stratification, and were planted in plastic containers filled with pine bark substrate. When the trunk widths of the rootstocks had reached $\sim 4.5 \mathrm{~mm}$ (December 2010), scion cultivar was grafted by vegetative bud grafting (inverse "T"), at a trunk height of $15 \mathrm{~cm}$ from the ground level. The seedlings were kept in worktops protected by a shading net, until the moment that they were transferred to the field.

\section{Rootstock by Minicutting (RM)}

Semi-hardwood minicuttings of rootstock Okinawa were obtained in March 2010, with two buds and a leaf cut in a half, which were treated with indole butyric acid (2000 mg. $\left.\mathrm{L}^{-1}\right)$, according to Timm et al. (2015), to help the rooting process. The substrates used were vermiculite and autoclaved sand $(1: 1 \mathrm{v} / \mathrm{v})$, the combination of which had been previously moistened with water and kept in a greenhouse at $25{ }^{\circ} \mathrm{C}$ for 60 days. When necessary, cuttings were dampened during rooting to avoid dehydration. The rooting cuttings were thereafter transferred to a greenhouse-bound semi-hydroponic system that uses plastic trays $(80 \times 20 \mathrm{~cm})$ containing a $5 \mathrm{~cm}$ layer of crushed stone for drainage, a layer of medium sand and shading net to avoid mixing these materials. During the production and development of the seedlings, the plastic trays were irrigated on a daily basis with a nutritive solution as described by Schuch and Peil (2012), as per the needs of the seedlings. Nutrient replenishment was determined by monitoring the electric conductivity and $\mathrm{pH}$ (kept between 5.5 and 6.5). When the trunk widths of the rootstocks had reached $\sim 4.5 \mathrm{~mm}$, scion cultivar was grafted by vegetative bud grafting (inverse "T"), at a trunk height of $15 \mathrm{~cm}$ from the ground level.
Grafted seedlings were kept in the semi-hydroponic system until they were transferred to the field.

\section{Self-Rooting (SR)}

Minicuttings of Maciel scion were propagated as described for the RM technique in early December 2010. After 60 days in a greenhouse (late February), cuttings were transferred to a semi-hydroponic system and cultivated as described for the RM technique. The semi-hydroponic system used in this study was set out as per Schuch e Peil (2012) and the composition of the nutritive solution is not shown because it, at the time of publication, was in the process of being patented.

Nursery trees were planted at the experimental field of at Federal University of Pelotas in August 2011 , at $5.0 \times 1.4 \mathrm{~m}$ spacing, and trained as a "Y" system. The experimental design involved a randomized complete block with four replications of three plants each. A tree was planted as a buffer at the start and end of each plot. Soil fertility was analyzed and was found to be appropriate. Treatments consisted of three different propagation methods as described above: 1) Conventional System (CS); 2) Rootstock by Minicutting (RM) and; 3) Self-Rooting (SR).

The vegetative growth of the trees was evaluated by measuring trunk diameter increment, length, and diameter of main scaffolds, length of current-season productive shoots, fresh weight of pruned shoots and canopy volume, using the following equation, according to Rocha et al. (2007):

$$
V=\frac{\left[\left(\frac{L}{2}\right) \times\left(\frac{E}{2}\right) \times(A) \times(\pi)\right]}{3}
$$

where $\mathrm{V}$ is the canopy volume, $\mathrm{L}$ represents the upper distance between scaffolds, $\mathrm{E}$ is the average width between the two scaffolds, and $\mathrm{A}$ is the canopy height

Fruits were harvested when they were visually assessed to be mature i.e. their background skin 
color. At harvest, the fruits were counted and weighed in order to calculate the fruit fresh weight $(\mathrm{g})$, the average production per tree $(\mathrm{kg})$, and the estimated production per hectare (t.ha $\left.{ }^{-1}\right)$. Samples of 20 randomly selected fruits per replication were analyzed for fruit quality.

Sampled fruits were analyzed and compared according to their: fruit diameter (mm), measured with a digital caliper; flesh firmness (FF, Newton), measured with a digital penetrometer using an 8 $\mathrm{mm}$ probe; skin color ( $\mathrm{SC}, \Delta \mathrm{E}$ ), confirmed with a Minolta ${ }^{\circledR}$ colorimeter; soluble solids (SS, ${ }^{\circ}$ Brix), measured using a digital refractometer; and titratable acidity (TA - meq $\left.100 \mathrm{~mL}^{-1}\right)$, measured by neutralizing titration with $\mathrm{NaOH} 0,1 \mathrm{~N}$. Fruit color was determined by color difference $(\Delta \mathrm{E})$, taking into account the three-dimensional scale $L^{*} a^{*} b^{*}$, through the equation:

$$
\left[\left(L^{*}-\mu L^{*}\right)^{2}+\left(a^{*}-\mu a^{*}\right)^{2}+\left(b^{*}-\mu b^{*}\right)^{2}\right]^{0.5}
$$

where $L^{*}$ is the lightness coefficient, ranging from black (0) to white (100); $\mathrm{a}^{*}$ and $\mathrm{b}^{*}$ indicate color direction: values of $\mathrm{a}^{*}$ may be positive (red) or negative (green), and values of $b^{*}$ may be positive (yellow) or negative (blue).

Statistical analyses were performed using the $\mathrm{R}$ software. Treatment means were compared using analysis of variance (ANOVA) and significance was tested at $\mathrm{P} \leq 0.05$. Mean separation was determined by Tukey's test.
The vegetative parameters of the trees that resulted from the CS and SR techniques showed greater trunk diameters and scaffold increments and average scaffold length (Table 1). When comparing both the cutting treatments, RM and SR, the trees from the latter technique were found to have greater vegetative growth. When considering the growth increment, a similar behavior was observed for trunk and scaffold diameter, which essentially increased from October to April. The greater initial vegetative growth of CS trees may be explained because the rootstock of this treatment was sexually propagated (i.e. from seed). This method confers high initial vegetative growth to the trees due to juvenility characteristics, which corresponds to the early vigorous vegetative growth stage of the seedlings after germination, during which flowering cannot be induced even if environmental conditions are favorable (XAVIER et al., 2009).

Greater vegetative growth was observed in SR propagated trees than in $\mathrm{RM}$ propagated trees. A possible explanation for this observation is the absence of grafting incompatibility in SR propagated trees, since grafting was not applied in this treatment, as opposed to the RM propagation technique. According to the literature, self-rooted scion cultivars may have a high capacity for nutrient uptake from the soil, a better uniformity of shoot growth, and eliminate the chance of tree losses due to graft incompatibility (TWORKOSKI; TAKEDA, 2007).

Table 1. Parameters of vegetative growth of Maciel peach trees produced by three propagation methods: Conventional System (CS), Rootstock by Minicutting (RM), and Self-Rooting (SR).

\begin{tabular}{ccccccc}
\hline Treatment & $\begin{array}{c}\text { Trunk Diameter } \\
\text { Increment }(\mathrm{mm})\end{array}$ & $\begin{array}{c}\text { Scaffold Diam- } \\
\text { eter }(\mathrm{mm})\end{array}$ & $\begin{array}{c}\text { Scaffold } \\
\text { Length }(\mathrm{cm})\end{array}$ & $\begin{array}{c}\text { Shoot } \\
\text { Length }(\mathrm{cm})\end{array}$ & $\begin{array}{c}\text { Pruning } \\
\text { weight }(\mathrm{kg})\end{array}$ & $\begin{array}{c}\text { Canopy Vol- } \\
\text { ume }\left(\mathrm{m}^{3}\right)\end{array}$ \\
\hline $\mathrm{CS}$ & $33.2 \mathrm{a}^{\mathrm{z}}$ & $30.0 \mathrm{a}$ & $165.8 \mathrm{a}$ & 40.7 & 4.8 & 2.84 \\
$\mathrm{RM}$ & $26.9 \mathrm{~b}$ & $22.2 \mathrm{~b}$ & $136.2 \mathrm{~b}$ & 36.8 & 4.5 & 3.28 \\
$\mathrm{SR}$ & $31.8 \mathrm{a}$ & $28.1 \mathrm{a}$ & $169.9 \mathrm{a}$ & 37.7 & 5.5 & 2.87 \\
& & & & & & \\
$\mathrm{CV}(\%)$ & 5.8 & 6.1 & 7.3 & 4.91 & 9.6 & 19.2 \\
$P>F$ & 0.006 & 0.001 & 0.012 & 0.062 & 0.063 & 0.521 \\
\hline
\end{tabular}

${ }^{\mathrm{z}}$ Mean separation within columns by Tukey's test at $P<0.05$; means followed by different letters are significantly different.

* CV- coefficient of variation. 
RM propagated trees showed lower trunk diameter increments than the other treatments, from the initiation of the trial to the end of the first growing season. Similar behavior was found for the variable responses of the scaffold length increments, where two noticeable peaks of growth occurred in December and March. No differences were found for average length of current-year shoots, fresh weight of pruning and canopy volume. The lower vegetative growth of RM propagated trees is a probably a result of the use of cutting propagation (rootstock) and grafting (scion). Both methods are characteristically vigor-reducing when compared to seed propagation (FACHINELLO et al., 2005). Vigor reduction might be interesting, for instance, if one desires more compact trees for highdensity plantings. The vegetative growth peak in December, shown through the higher scaffold length increments, was probably due to the occurrence of high temperatures and, in March, due to the tree response to postharvest fertilizer application, performed to improve plant nutrition and keep the leaves on the trees for as long as possible.

Fruit production at the time of harvesting, concentrated between 14 and 21 December, showed a similar pattern for all treatments. During the first harvest of RM trees (11 Dec), a proportionally lower amount of fruit was harvested. SR propagated trees showed a similar production of fruit to that of the CS propagated trees. In the first growing season, in which fruit was produced (2012), treatments did not significantly differ in production, yield, fruit weight, fruit diameter, soluble solids, $\mathrm{pH}$, fruit color and fruit firmness (Table 2). This lack of significant differences was probably due the low amount of fruits harvested, since trees were still very young (at the $2^{\text {nd }}$ leaf stage). On the other hand, in the 2013 growing season, differences were found among treatments. The greater fruit weight and fruit diameter observed in the RM treatments could be explained by its lower production per tree and consequently a reduced source/sink relationship and competition for carbohydrates (BYERS et al., 2003).

SR-propagated Maciel trees had a higher production and estimated yield than the CS trees (Table 2), although this difference was not found to be statistically significant. The production of CS and RM trees (both grafted on the cultivar Okinawa, but by different propagation methods of the rootstock) were not found to differ from one another. The greater production of SR trees might be related to the absence of graft incompatibility (COLOMBO; NÉRI, 2003). In this sense, the use of this method might be a suitable option for sites where the use of rootstocks does not present any clear advantage, such as nematode resistance (OLIVEIRA et al., 2003). A study of vegetative propagation of selfrooted Maciel plants through minicuttings in a semi-hydroponic system, concluded that this system improves the development of self-rooted peach seedlings (rooting $>90 \%$ ) compared to propagation through minicuttings in plastic bags (TOMAZ, 2014). The cutting method combined with the semihydroponic system could, therefore, be an interesting alternative to seed propagation, because it provides better tree uniformity (excludes the possibility of genetic variability), reduces of the time needed for seedling production, and increases the possibility of producing well-nourished seedlings with strong root systems (TOMAZ, 2014). 
Table 2. Parameters of fruit from Maciel peach trees produced by three propagation methods: Conventional System (CS), Rootstock by Minicutting (RM), and Self-Rooting (SR).

\begin{tabular}{|c|c|c|c|c|c|c|c|c|c|}
\hline Treatment & $\begin{array}{l}\text { Product. } \\
\text { per tree } \\
(\mathrm{kg})\end{array}$ & $\begin{array}{l}\text { Estimated } \\
\text { Yield } \\
\left(\text { ton } \text { ha }^{-1}\right)\end{array}$ & $\begin{array}{c}\text { Fruit } \\
\text { Weight } \\
\text { (g) }\end{array}$ & $\begin{array}{c}\text { Fruit } \\
\text { Diameter } \\
(\mathrm{mm})\end{array}$ & $\begin{array}{l}\text { Soluble } \\
\text { Solids } \\
\left({ }^{\circ} \text { Brix) }\right.\end{array}$ & $\mathrm{pH}$ & $\begin{array}{l}\text { Titratable acid- } \\
\text { ity } \quad \text { (meq } \\
\left.100 \mathrm{~mL}^{-1}\right)\end{array}$ & $\begin{array}{l}\text { Fruit } \\
\text { Color } \\
(\Delta \mathrm{E})\end{array}$ & $\begin{array}{l}\text { Fruit } \\
\text { Firmness } \\
(\mathrm{N})\end{array}$ \\
\hline \multicolumn{10}{|c|}{ (c) } \\
\hline $\mathrm{CS}$ & 1.4 & 2 & 95.8 & 60.5 & 12.6 & 3.3 & $14.8 \mathrm{a}$ & 5.4 & 51.1 \\
\hline RM & 0.8 & 1.2 & 106.1 & 63 & 11.9 & 3.2 & $11.3 \mathrm{~b}$ & 5.7 & 48.9 \\
\hline SR & 1.3 & 1.9 & 105.8 & 62.8 & 12.3 & 3.2 & $11.6 \mathrm{~b}$ & 4.9 & 51.5 \\
\hline CV $(\%)$ & 29.4 & 29.5 & 6.5 & 2.4 & 8.45 & 4.2 & 10 & 52.7 & 12.3 \\
\hline$P>F$ & 0.117 & 0.115 & 0.127 & 0.095 & 0.646 & 0.688 & 0.013 & 0.907 & 0.819 \\
\hline \multicolumn{10}{|c|}{ 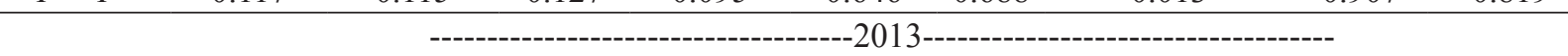 } \\
\hline $\mathrm{CS}$ & $10.0 \mathrm{ab}^{\mathrm{z}}$ & $14.3 \mathrm{ab}$ & $131.6 \mathrm{~b}$ & $61.0 \mathrm{~b}$ & 13.7 & 3.7 & 6.3 & $2.6 \mathrm{~b}$ & 38.8 \\
\hline RM & $8.8 \mathrm{~b}$ & $12.6 \mathrm{~b}$ & $147.1 \mathrm{a}$ & $63.5 \mathrm{a}$ & 12.8 & 3.6 & 6.9 & $3.4 \mathrm{ab}$ & 34.4 \\
\hline SR & $11.2 \mathrm{a}$ & $16 \mathrm{a}$ & $127.4 \mathrm{~b}$ & $60.9 \mathrm{~b}$ & 12.5 & 3.7 & 7.3 & $4.0 \mathrm{a}$ & 35.2 \\
\hline CV (\%) & 6.8 & 6.8 & 3.6 & 1.3 & 4.5 & 2.1 & 10.8 & 16.8 & 8.9 \\
\hline$P>F$ & 0.007 & 0.007 & 0.003 & 0.006 & 0.067 & 0.422 & 0.218 & 0.027 & 0.21 \\
\hline
\end{tabular}

${ }^{z}$ Mean separation within columns by Tukey's test at $P<0.05$; means followed by different letters are significantly different.

* CV- coefficient of variation.

Maciel cultivar peach trees propagated by the SR technique have field performance similar or even superior to that of trees obtained by CS propagation. It is, therefore, reasonable to assert that SR is a suitable alternative technique for peach propagation, depending on the production area, i.e., where the exclusion of rootstock will not result in losses due to impeding factors neutralized by the rootstock, like nematodes, soil diseases, etc. Additionally, based on the field performance of $\mathrm{RM}$ trees, this propagation method seems to be an important alternative to seed propagation and, more importantly, is also practical if the goal is highdensity planting, since this method combines two vigor-reducing techniques (cutting and grafting). Further studies are necessary in order to check the field performance of other peach cultivars and sites.

\section{References}

BATI, C. B.; GODINO, G.; MONARDO, D.; NUZZO, V. Influence of propagation techniques on growth and yield of olive tree cultivars 'Carolea' and 'NocellaraEtnea'.
Scientia Horticulturae, Alexandria, v. 109, n. 2, p. 173182, 2006.

BYERS, R. B.; COSTA, G.; VIZZOTTO, G. Flower and fruit thinning of peach and other prunus. Horticultural Reviews, West Lafayette, v. 28, n. 1, p. 351-392, 2003.

CARDOSO, C.; YAMAMOTO, L. Y.; PRETI, E. A.; ASSIS, A. M.; NEVES, C. S. V. J.; ROBERTO, S.R. AIB e substratos no enraizamento de estacas de pessegueiro 'Okinawa' coletadas no outono. Semina: Ciências Agrárias, Londrina, v. 32, n. 4, p. 1307-1314, 2011.

COLOMBO, R.; NÉRI, C. M. Portinnesti del Pero, un modello vincente. La Tecnica L'Impianto del Frutteto, Imola (BO), 72-74, 2003. Available at: <http://www. ermesagricoltura.it/rivista/2003/settembre/RA030972s. pdf $>$. Accessed at: 18 jan. 2015.

FACHINELLO, J. C.; HOFFMANN, A.; NACHIGAL, J. C. Propagação de plantas frutiferas. Brasília, DF: Embrapa Informação Tecnológica, 2005. 221 p.

HAMMERSCHLANG，F. A.; SCORZA， R. Field performance of micropropagated, own-rooted peach trees. Journal of the American Society for Horticultural Science, Alexandria, v. 116, n. 6, p. 1089-1091, 1991.

MARÍN, J. A.; CASTILLO, M.; GARCÍA, E.; ANDREU, P. Field performance of grafted fruit-tree rootstocks was not affected by micropropagation. Acta Horticulturae, 
Sani-Halkidiki, v. 616, n. 1, p. 295-299, 2003.

OliveIRA, A. P.; NIENOW, A. A.; CALVETE, E. O. Capacidade de enraizamento de estacas semilenhosas e de cultivares de pessegueiro tratadas com AIB. Revista Brasileira de Fruticultura, Jaboticabal, v. 25, n. 2, p. 282-285, 2003.

PICOLOTTO, L.; BIANCHI, V. J.; GAZOLLA NETO, A.; FACHINELLO, J. C. Diferentes misturas de substrato na formação de mudas de pessegueiro em embalagem. Scientia Agricola, Piracicaba, v. 8, n. 2, p. 119-125, 2007.

ROCHA, M. S.; BIANCHI, V. J.; FACHINELLO, J. C.; SCHMITZ, J. D.; PASA, M. S.; SILVA, J. B. Comportamento agronômico inicial da cv. Chimarrita enxertada em cinco porta-enxertos de pessegueiro. Revista Brasileira de Fruticultura, Jaboticabal, v. 29, n. 3, p. 583-588. 2007.

SCHUCH, M. W.; PEIL, R. M. N. Soilless cultivation systems: A new approach in fruit plants propagation in southern Brazil. Acta Horticulturae, Athens, v. 952, n. 1, p. 877-883, 2012.

SOUZA, A. L. K. SCHUCH, M. W.; ANTUNES, L. E. C.; SCHMITZ, J. D.; PASA, M. S.; CAMARGO, S. S.; CARRA, B. Desempenho de mudas de mirtilo obtidas por micropropagação ou estaquia. Pesquisa Agropecuária Brasileira, Brasília, v. 46, n. 8, p. 868-874, 2011.

TIMM, C. R. F.; SCHUCH, M. W.; TOMAZ, Z. F. P.; MAYER, N. A. Enraizamento de miniestacas herbáceas de porta-enxertos de pessegueiro sob efeito de ácido indolbutírico. Semina: Ciências Agrárias, Londrina, v. 36, n. 1, p. 135-140, 2015.

TOFANELLI, M. B. D.; RODRIGUES, J. D.; ONO, E. O. 2,6-Di-hidroxiacetofenona e tipo de corte basal no enraizamento de estacas semi-lenhosas de pessegueiro 'Okinawa'. Ciência Rural, Santa Maria, v. 35, n. 2, p. 462-464, 2005.

TOMAZ, Z. F. P.; SCHUCH, M. W.; PEIL, R. M. N.; TIMM, C. R. F. Desenvolvimento de porta-enxertos de pessegueiro obtidos de miniestacas, em duas épocas e sistema de cultivo sem solo. Revista Brasileira de Fruticultura, Jaboticabal, v. 36, n. 4, p. 988-995, 2014.

TSIPOURIDIS, C.; THOMIDIS, T.; BLADENOPOULOU, S. Seasonal variation in sprouting of GF677 peach almond (Prunus persica' Prunus aygdalus) hybrid root cuttings. Journal of Crop and Horticultural Science, Sidney, v. 34, n. 1, p. 45-50, 2006.

TWORKOSKI, T.; TAKEDA, F. Rooting response of shoot cuttings from three peach growth habits. Scientia Horticulturae, Alexandria, v. 115, n. 1, p. 98-100, 2007.

XAVIER, A.; WENDLING, I.; SILVA, R. L. Silvicultura clonal: princípios e técnicas. Viçosa, MG: Editora UFV, 2009. 272 p. Available at: <http://www.abeu.org.br/farol/ abeu/catalogo-unificado/item/editoraufv/silviculturaclonal---principios-e-tecnicas-- $2 \% \mathrm{C} 2 \% \mathrm{AA}-$ edicao/4358/>. Accessed at: 15 maio 2015. 
